\title{
ASSIMILATE PARTITIONING AND PHYTOTOXICITY IN SOYBEAN PLANTS TREATED WITH HERBICIDES1
}

\author{
RICARDO A. MARENCO ${ }^{2}$, NEI F. LOPES $^{3}$
}

\section{RESUMO}

\section{Partição de assimilados e fitotoxicidade em plantas de soja tratadas com herbicidas}

O ef ei to dos herbicidas triflural in, clorimuron e clomazone sobre a morfologia e partição de assimilados foram avaliados durante o desenvolvimento da soja, cultivada em casa de ve ge ta çã o. As am os tras fora $m$ cole tada s a intervalos de 14 dias. Clomazone reduziu o acúmulo de matéria seca nos caules e folhas aos 14 dias após a emergência (DAE), enquanto que trifluralin e clorimuron reduziram o acúmulo de matéria seca até os 28 DAE. O número de folhas, a altura de planta, a massa e o número de vagens e sementes, bem como a relação parte aérea/raiz não foram influenciadas pelos herbicidas. As raízes, os caules e as folhas foram os drenos preferidos até o estádio R2. posteriormente, as vagens e sementes em desenvolvimento tornaram -se os drenos preferidos, esta seqüência não foi alterada pelos herbicidas.

Palavras chave: trifluralin, clorimuron, clomazone, partição de assimilados, herbicidas.

\begin{abstract}
To investigate the effects of trifluralin, chlorimuron and clomazone on morphology and assimilate partitioning during soybean development, plants were grown in a greenhouse and sampled at 14-day intervals. Clomazone reduced stem and leaf dry matter accumulation at 14 days after emergence (DAE), while trifluralin and chlorimuron reduced plant part dry matter accumulation up to $28 \mathrm{DAE}$. The number of
\end{abstract}

ABSTRACT leaves, plant height, mass and number of pods and seeds, and the shoot/root ratio were not influenced by the herbicides. Roots, stems and leaves were the preferred sinks up to the $\mathrm{R}_{2}$ growth stage, while pods and developing seeds became the preferred sinks later. This order was not altered by the herbicides.

Key word s: tr if lu ra li n, ch lo rimuron, clomazone, assimilate partitioning, herbicides.

${ }^{1}$ Recebido para publicação em 29/11/94 e na forma revisada em 10/06/96.

${ }^{2}$ Prof. Visitante, Centro de Ciências Agrárias, Universidade Estadual do Maranhão, Caixa Postal 9, CEP 65.054-970, São Luís, MA.

${ }^{3}$ Prof. Titular, Depto. de Biologia Vegetal, Universidade Federal de Viçosa, CEP 36.570-000, Viçosa. MG. 


\section{INTRODUCTION}

In soybean production several methods are used to reduce weed competition, but the control of weeds with herbicides is probably one of the most widely used methods throughout the world. Howe ver, herbicidal effects on soybean plant growth have not been entirely established, even for the earlier used herbicides.

Trifluralin reduced shoot and root dry matter accumulation in four-week-old soybean plan ts (Kurt \& Struck meyer, 1971). It al so reduced shoot and root dry matter in 40-day-old Trifolium sp., another leguminous plant (Brock, 1972). Chlorimuron inhibits the biosynthesis of branched-chain amino acids, valine and leucine (Beyer et al., 1988), and clomazone disrupts the biosynthesis of carotenoids (Duke, 1990). During the first vegetative stages, trifluralin, chorimuron and clomazone influenced both nitrogen fixation (Marenco et al., 1993) and nitrogen concentration of soybeans (Marenco \& Lopes, 1994).

This study was undertaken to evaluate the effects of chlorimuron, trifluralin and clomazone on morphology, assimilate partitioning and rates of dry matter accumulation in soybean plant parts.

\section{MATERIALS AND METHODS}

Soybean seeds (Glycine max (L.) Merrill cv. Uberlandia), inoculated with Bradvrhizobium iaponic um, we re grow $\mathrm{n}$ under greenhouse conditions. Temperature ranged from 21 to $23^{\circ} \mathrm{C}$ at night to a maximum of 33 to $39^{\circ} \mathrm{C}$ during the day; relative humidity varied from 38 to $60 \%$ during the day to a maximum of nearly $100 \%$ at night; photoperiod was $14 \pm 1 \mathrm{~h}$. Plants grew in 4L pots on a moderately fertile Red-Yell ow Latossol, collected from 0 to $0.2 \mathrm{~m}$ depth, with clay texture and $3.2 \%$ organic matter. The soil was amended with $0.9 \mathrm{~g}$ lime $/ \mathrm{kg}$ soil, fertilized with $400 \mathrm{mg}$ P/kg soil, $50 \mathrm{mg} \mathrm{K} / \mathrm{kg}$ soil and kept near field capacity during plant development.
After emergence, the seedlings were thinned to two per pot to obtain an average of 15 plant $/ \mathrm{m}$ -

The experimental design was a randomized complete block with treatments in split-plot with three replications (R), with sampling dates (D) and herbicide (H) treatments as the main plots and plots, respectively. The herbicides tested were chlorimuron $(7,10.5$ and $14.0 \mathrm{~g} / \mathrm{ha}$ a.i.), trifluralin $(800,1200$ and $1600 \mathrm{~g} / \mathrm{ha}$ a.i.) and clomazone (800, 1200 and $1600 \mathrm{~g} / \mathrm{ha}$ a.i.). An untreated control was also included. Thus, the degrees of freedom (df) in the analysis of variance were the following: a) replications (R-1), $2 \mathrm{df}$; sampling dates (D-1), 8 df; error-a [(R-1) x (D1)], $16 \mathrm{df}$; herbicides (H-1), 9 df; interaction [(H1) x (D-1)], $72 \mathrm{df}$; error-b [D (R-1) x (H-1)], 162 df. The herbicide were applied with a backpack sprayer spraying about $400 \mathrm{~L} / \mathrm{ha}$ at $230 \mathrm{kPa}$. through flat fan nozzles. Trifluralin was incorporated immediately after application. Clomazone was applied to the soil surface just after planting, where as chlorimuron was applied 14 DAE. At each sampling occasion, the growth stage of plants was recorded (Fehr et al., 1971). Leaves (blade only), stems (stems and petioles), roots and pods from each plant were separated and dried at $75^{\circ} \mathrm{C}$ until constant mass, and weighed.

Mean values of dry matter of leaves $\left(\mathrm{W}_{\mathrm{f}}\right)$, stems $\left(\mathrm{W}_{\mathrm{s}}\right)$ and roots $\left(\mathrm{W}_{\mathrm{r}}\right)$, throughout plant development, were fitted by polynomial equations, using least squares techniques in the regression analysis. Dry matter of pods $\left(\mathrm{W}_{1}\right)$, pod walls $\left(\mathrm{W}_{\mathrm{p}}\right)$ and seeds $\left(\mathrm{W}_{\mathrm{g}}\right)$ were fitted by a logistic model. $\mathrm{W}=\mathrm{W}_{\mathrm{m}} /\left(1+\mathrm{Be}^{-\mathrm{Ct}}\right)$, where $\mathrm{W}_{\mathrm{m}}$ is the estimate of the maximum plant part dry matter accumulation, $B$ and $C$ are fitting coefficients, and $t$ is time in days after emergence.

The rates of plant part dry matter accumulation were obtained by differentiating the equations previously fitted for each plant part with respect to time (Radford, 1967). Reproductive partitioning coefficients $\left(P_{c}\right)$ were determined from the $R_{3}$ to $R_{8}$ growth stage, being $\mathrm{P}_{\mathrm{c}}=100 \times \mathrm{W}_{1} / \mathrm{W}_{\mathrm{t}}$, where $\mathrm{W}_{\mathrm{t}}$ is the total plant dry matter accumulation. The harvest index $\left(\mathrm{H}_{\mathrm{i}}\right)$ was 
calculated at the $\mathrm{R}_{8}$ stage, being $\mathrm{H}_{\mathrm{i}}=\mathrm{W}_{\mathrm{g}} / \mathrm{W}_{\mathrm{t}}$ (Egli et al., 1985).

\section{RESULTS AND DISCUSSION}

Herbicide application reduced significantly $(\mathrm{P} \leq 0.05)$ dry matter accumulation in sterns, leaves and roots during the first four weeks after plant emergence. In older plants no effect of herbicides was observed. At 14 DAE, trifluralin reduced dry matter accumulation in both leaves, from 0.35 to $0.20 \mathrm{~g} / \mathrm{plant}$, and stems, from 0.16 to $0.10 \mathrm{~g} /$ plant (Figure 1A). Similar effects were caused by clomazone (Figure 1B,C). At 28 DAE, triflural in reduced dry matter accumulation in both leaves, from 2.12 to $1.39 \mathrm{~g} / \mathrm{plant}$, and stems, from 1.66 to $125 \mathrm{~g} /$ plant (Figure ID). At the same sampling occasion, chlorimu ron reduced dry matter of leaves from 2.12 to $1.65 \mathrm{~g} / \mathrm{plant}$ : stems from 1.66 to $1.36 \mathrm{~g} / \mathrm{plant}$, and roots from 0.65 to $0.49 \mathrm{~g} /$ plant (Figure 2). After $28 \mathrm{DAE}$, there was no effect of clomazone on plant part dry matter accumulation (data not shown).

The effect of trifluralin on leaf and stem dry matter accumulation is similar to that ob se rved previously, in soybeans (Kust \& Struckmeyer, 1971) or Trifolium and Lotus spp (Brock, 1972). This may be due to its direct effect on both cell division (Duke, 1990) and translocation of nutrients (Kust \& Struckmeyer,

1971). Trifluralin effect on dry matter accumulation was greater at 14 than at $28 \mathrm{DAE}$, which may be due to root growth beyond the treated soil zone as well as herbicide degradation with time. Similar responses of soybeans to trifluralin application were observed by Kust \& Struckmeyer (1971). Chlorimuron and clomazone disrupt several metabolic processes in sensitive species, which acting at different times or simultaneously could explain their detrimental effect on dry matter accumulation in soybean plants.
After 28 DAE, there were no effects of her bicides on dry matter accumulation in any plant part. The refore, the dat a were pooled to analyze accumulation of dry matter (Figure 3A) and rates of dry matter accumulation in relation to days after emergence (Figure 3B). Leaf and stem dry matter accumulation increased with plant age up to $100 \mathrm{DAE}, \mathrm{R}_{6}$ growth stage, which was due to the production of lateral branches during the pod filling stages. Sterns and roots showed a small reduction in dry matter during the last reproductive stages, whereas dry matter of leaves decreased from 12.7 at $84 \mathrm{DAE}$ to $10.5 \mathrm{~g} / \mathrm{plant}$ at 126 DAE (Figure 3A). Thus, it may be suggested that the leaves were the main source of assimilate remobilized from vegetative parts to developing seeds. This is in agreement with rates of assimilate reallocation observed in cowpea (Vigna unguiculata (L.) Walp), another leguminous plant (Peoples \& Gifford, 1990).

Seed dry matter accumulation increased with time following a logistic pattern (Figure 4A). It rose from 4.32 at $R_{6}$ to $23.64 \mathrm{~g} / \mathrm{plant}$ $\left(354.6 \mathrm{mg} / \mathrm{m}^{2}\right.$ ) at the $\mathrm{R}_{8}$ grow th stage (Table 1 ). At the end of the reproductive phase, seed dry matter increased due to the production of pods and seeds still at the $\mathrm{R}_{5}$ and $\mathrm{R}_{6}$ growth stages.

The preferred metabolic sinks for as similate allocation changed as the plants underwent morphological transformations. At the beginning of plant development, the stems, roots, and leaves were, in this order, the preferred sinks (Figure 3B), whereas the pods and developing seeds were the most important sinks later (Figure 4B). On average, the greatest rates of dry matter accumulation were 232, 221 and $67 \mathrm{mg} /$ (plant.day) for sterns, leaves and roots, respectively (Figure 3B). Rates of dry matter accumulation were greater in stems $\left(C_{s}\right)$ than in leaves $\left(C_{1}\right)$, which is consistent with the greater influence of $\mathrm{W}_{\mathrm{s}}$ on $\mathrm{W}_{\mathrm{t}}$ during the vegetative period. 
The highest rates of dry matter accumulation in pod walls, $360 \mathrm{mg} /$ (plant.day) and pods, $1050 \mathrm{mg} /$ (plant.day), were observed at 92 and 105 DAE, respectively, whereas in the seeds, the maximum rate of dry matter accumulation $\left(\mathrm{C}_{\mathrm{g}}\right), 810 \mathrm{mg} /$ (plant.day), about $12 \mathrm{~g} /\left(\mathrm{m}^{2}\right.$.day $)$, was attained at 110 DAE (Figure 4B).
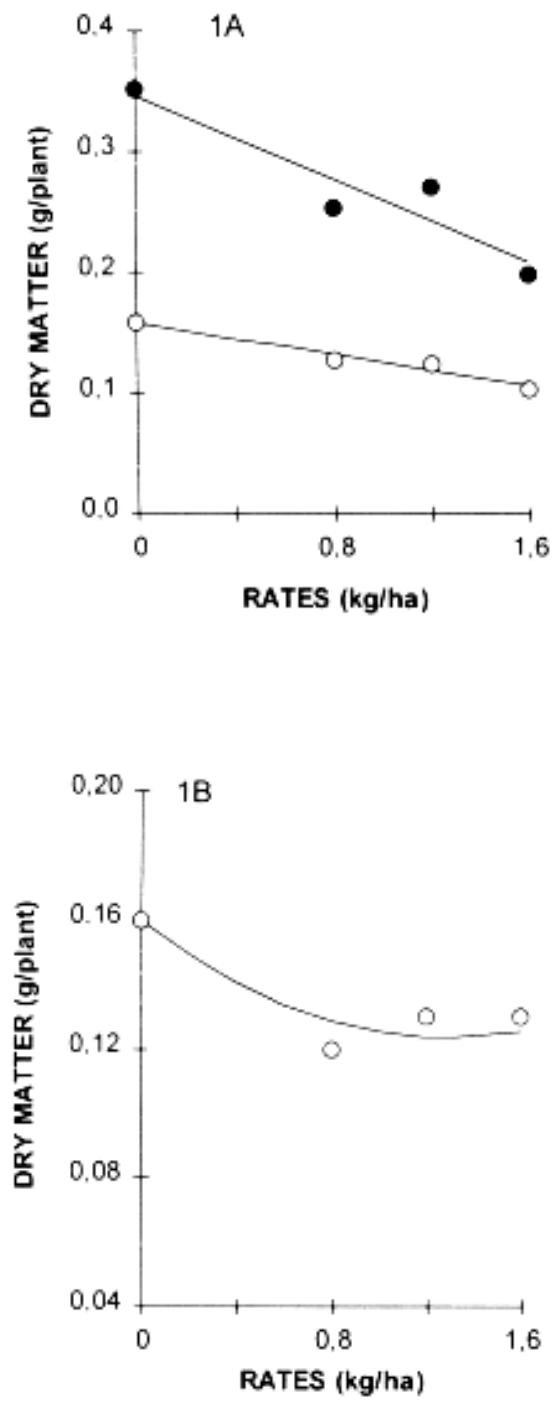
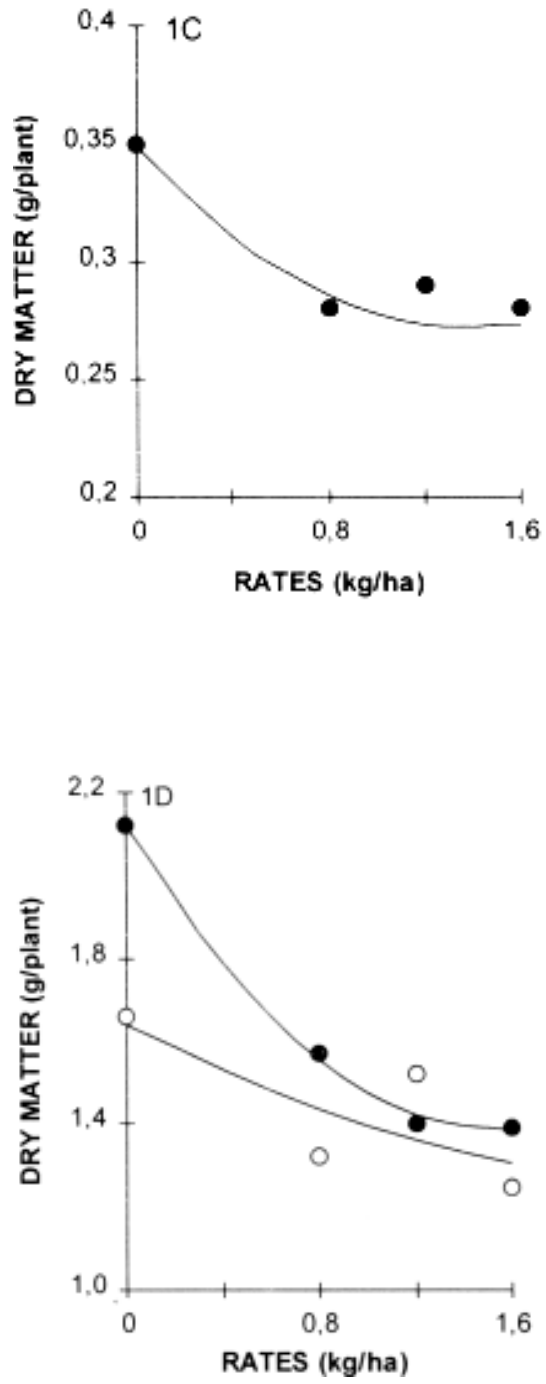

FIGURE 1 - Stem $(\mathrm{o})$ and leaf $(\bullet)$ dry matter of soybean plants after treatment with trifluralin $(\mathrm{A})$ and clomazone (B,C) evaluated at 14 DAE, trifluralin (D) evaluated at 28 DAE. Solid lines are fitted regressions, $(n=3): 1 \mathrm{~A}(0): \mathrm{Y}=0.15828-0.0325 \mathrm{~h}, \mathrm{r}^{2}=0.96 ; 1 \mathrm{~A}(\bullet): \mathrm{Y}=0.34717-$ $0.0868 \mathrm{~h}, \mathrm{r}^{2}=0.88 ; 1 \mathrm{~B}(\mathrm{o}): \mathrm{Y}=0.15976-0.0565 \mathrm{~h}+0.022 \mathrm{~h}^{2}, \mathrm{R}^{2}=0.96 ; 1 \mathrm{C}(\bullet): \mathrm{Y}=0.34864$ $-0.11 \mathrm{lh}+0.04 \mathrm{~h}^{2}, \mathrm{R}^{2}=0.94 ; \mathrm{ID}(\mathrm{o}): \mathrm{Y}=1.64-0.30056 \mathrm{~h}+0.05824 \mathrm{~h}^{2}, \mathrm{R}^{2}=0.61 ; 1 \mathrm{D}(\bullet): \mathrm{Y}$ $=2.12245-0.9556 \mathrm{~h}+0.31 \mathrm{~h}^{2}, \mathrm{R}^{2}=0.98$; were $h=$ rate of herbicide $(\mathrm{kg} / \mathrm{ha})$, and $Y=\operatorname{dry}$ matter in $\mathrm{g} /$ plant. 


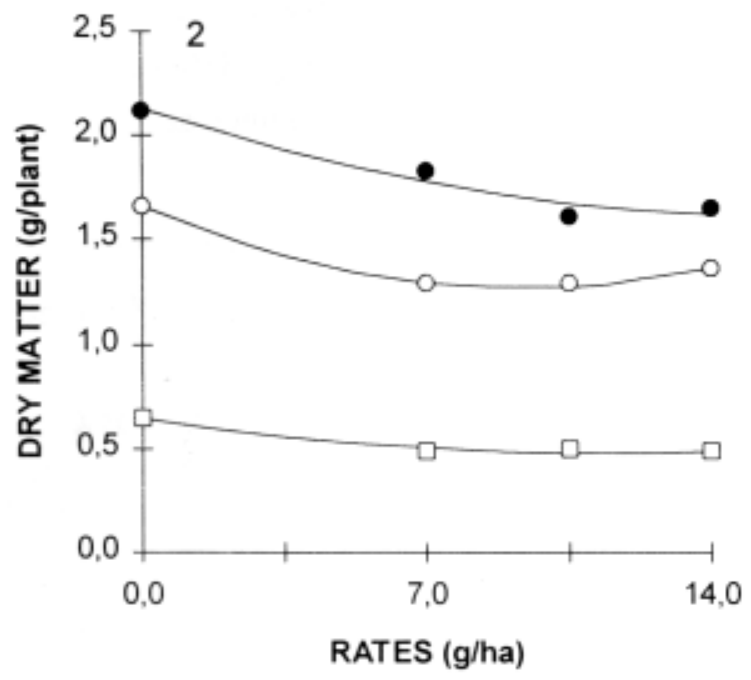

FIGURE 2. Dry matter accumulation in stems $(0)$, leaves $(\bullet)$ and roots $(\quad)$ of soybean plants treated with chlorimuron and assessed at 28 days after emergence. Solid lines are fitted regressions, $(\mathrm{n}=3): 2(\mathrm{o}): \mathrm{Y}=1.65855-0.081 .7923 \mathrm{~h}+0.00434138 \mathrm{~h}^{2}, \mathrm{R}^{2}=0.99 ; 2(\bullet): \mathrm{Y}=2.12845-$ $0.0637792 \mathrm{~h}+0.00198515 \mathrm{~h}^{2}, \mathrm{R}^{2}=0.95 ; 2(): \mathrm{Y}=0.648955-0.0292792 \mathrm{~h}+0.00127087 \mathrm{~h}^{2}$, $\mathrm{R}^{2}=0.98$; were $h=$ rate of herbicide $(\mathrm{g} / \mathrm{ha})$, and $Y=$ dry matter in $\mathrm{g} / \mathrm{plant}$
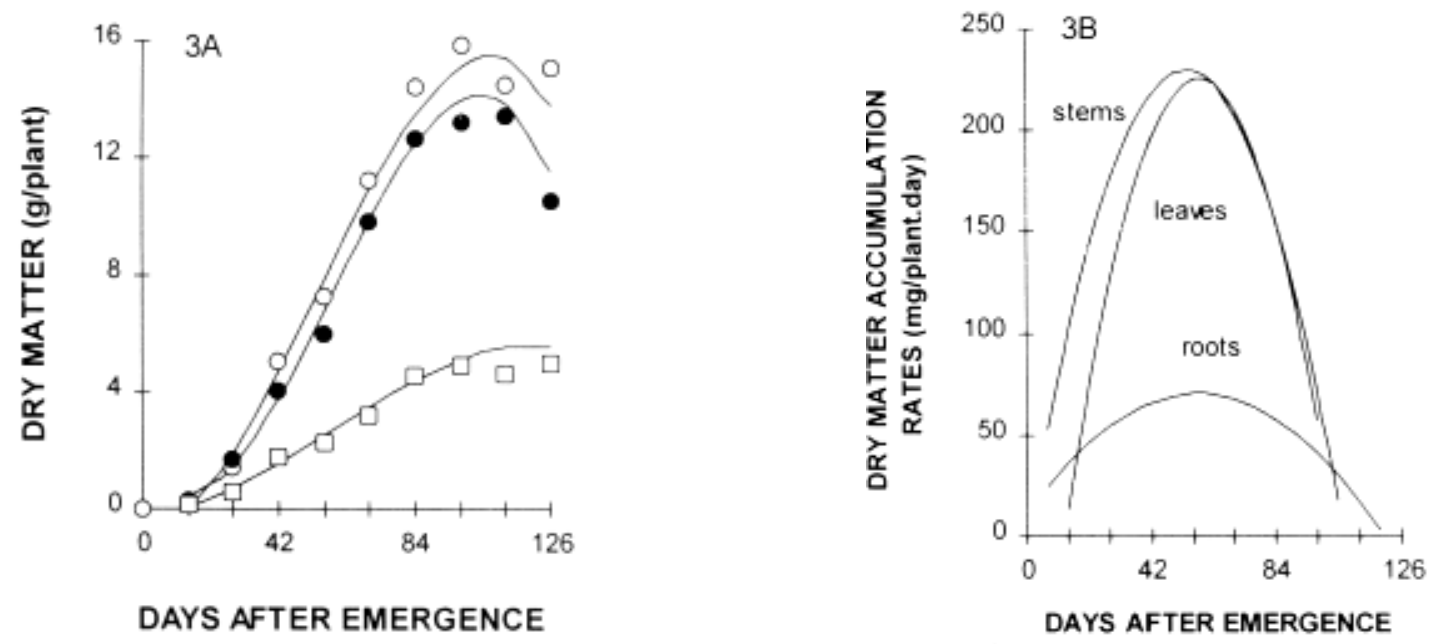

FIGURE 3. Dry matter of stems (o), leaves ( $\bullet$ ) and roots ( ) (A) and rates of dry matter accumulation (B) of soybean plants in relation to days after emergence. Solid lines are fitted regressions, $(\mathrm{n}=30): 3 \mathrm{~A}(\mathrm{o}): \mathrm{Y}=-0.842057-0.004154 \mathrm{t}+0.004356 \mathrm{t}^{2}-0.000027 \mathrm{t}^{3}, \mathrm{R}^{2}=0.99 ; 3 \mathrm{~A}(\bullet): \mathrm{Y}=$ $1.26853-0.142185 \mathrm{t}+0.006308 \mathrm{t}^{2}-0.000036 \mathrm{t}^{3}, \mathrm{R}^{2}=0.99 ; 3 \mathrm{~A}(\mathrm{)}): \mathrm{Y}=-0.27840+0.010869 \mathrm{t}$ $+0.001038 \mathrm{t}^{2}-0.000006 \mathrm{t}^{3}, \mathrm{R}^{2}=0.98$, where $t$ is the time after emergence, and $Y=$ dry matter in $\mathrm{g} /$ plant 


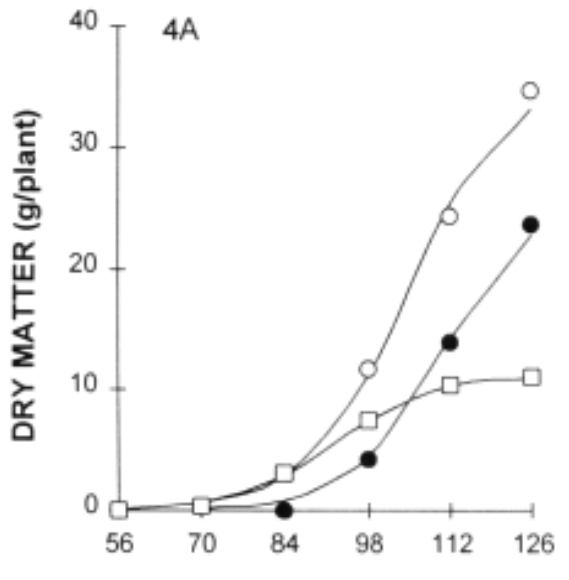

DAYS AFTER EMERGENCE

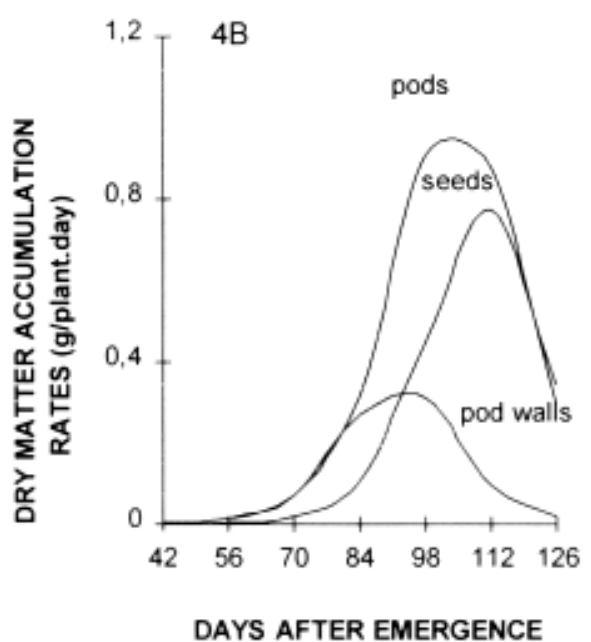

DAYS AFTER EMERGENCE

FIGURE 4. Dry matter of pods (o), seeds (•) and pod walls ( ) (A) and rates of dry matter accumulation (B) of soybean plants in relation to days after emergence. Solid lines are fitted regressions, $(\mathrm{n}=30): 4 \mathrm{~A}(\mathrm{o}): \mathrm{Y}=36.000 /\left(1+214916 \mathrm{e}^{(-0.11731 t)}\right), \quad \mathrm{R}^{2}=0.99: 4 \mathrm{~A}(\bullet): \mathrm{Y}=25.967 /(1+$ $\left.999990 \mathrm{e}^{(-0.12512 \mathrm{t})}\right), \mathrm{R}^{2}=0.99 ; 4 \mathrm{~A}(\mathrm{)}): \mathrm{Y}=11.168 /\left(1+134210 \mathrm{e}^{(-0.12783 \mathrm{t})}\right), \mathrm{R}^{2}=0.99$; where $t$ is the time after emergence, and $Y=$ dry matter in $\mathrm{g} / \mathrm{plant}$

TABLE 1. Stages of development, shoot-root ratio (SRR), dry matter of pods and seeds, partitioning coefficient $\left(\mathrm{P}_{\mathrm{c}}\right)$ and harvest index $\left(\mathrm{H}_{\mathrm{i}}\right)$ of soybean plants in relation to days after emergence, DAE, $(n=30)$.

\begin{tabular}{|c|c|c|c|c|c|c|}
\hline DAE & STAGES & SRR & $\begin{array}{l}\text { PODS } \\
\text { (g/plant) }\end{array}$ & $\begin{array}{l}\text { SEEDS } \\
\text { (g/plant) }\end{array}$ & $\begin{array}{l}\mathrm{Pc} \\
(\%)\end{array}$ & $\mathrm{H}_{\mathrm{i}}$ \\
\hline 14 & $\mathrm{v}_{3}$ & 3.47 & 0 & 0 & 0 & - \\
\hline 28 & $v_{7}$ & 5.57 & 0 & 0 & 0 & - \\
\hline 42 & $v_{10}$ & 4.46 & 0 & 0 & 0 & $\cdot$ \\
\hline 56 & $\mathrm{R}_{2}$ & 4.37 & 0 & 0 & 0 & . \\
\hline 70 & $\mathrm{R}_{3}$ & 4.40 & 0.33 & 0 & 1.26 & - \\
\hline 84 & $\mathbf{R}_{5}$ & 4.34 & 3.02 & 0 & 8.22 & . \\
\hline 98 & $R_{6}$ & 5.25 & 11.76 & 4.32 & 24.28 & - \\
\hline 112 & $\mathrm{R}_{7}$ & 6.77 & 24.34 & 14.02 & 40.81 & . \\
\hline 126 & $\mathrm{R}_{\mathrm{x}}$ & 9.04 & 34.69 & 23.64 & 52.00 & 0.3 \\
\hline $\mathrm{F}$ & . & $*$ & $*$ & .* & $*$ & ** \\
\hline $\mathrm{CV}(\%)$ & & 14 & 21 & 7 & 16 & - \\
\hline
\end{tabular}

** Significant at $\mathrm{P} \leq 0.01$ by the $\mathrm{F}$ test.

The herbicides did not affect significantly $(\mathrm{P}>0.05)$ the plant height and number of leaves, pods and seeds (data not shown). The same was true for the accumulation of dry matter in pods, 
seeds and pod walls as well as for the coefficient of partitioning $\left(\mathrm{P}_{\mathrm{c}}\right)$, harvest index $\left(\mathrm{H}_{\mathrm{i}}\right)$ and shoot/root ratio (SRR) (Table 1).

Pod production began at about 70 DAE, reaching the maximum (109 pods/plant) at the R6 grow th stage. Thereafter, it declined to 81 pods/plant at the R8 growth stage. Thus, there was a $26 \%$ pod loss with time. At the $\mathrm{R}_{8}$ growth stage there were 176 seeds/plant and 2.2 seeds per pod.

The $\mathrm{P}_{\mathrm{c}}$ increased rapidly with $\mathrm{plant}$ ontogeny, being 1.26 and 52\% at the R3 and R8 grow th stages, respectively (Table 1$)$. The shoot/root ratio increased with time, being 9.04 at the $R_{8}$ growth stage. Since there was no effect of herbicides on the SRR $(P>0.05)$, it may be suggested that they had similar influence on both shoots and roots. This is in agreement with Brock (1972) who observed reduction in both shoot and root dry matter accumulation without any effect on the shoot/root ratio.

From this study it may be concluded that chlorimuron, trifluralin and clomazone may reduce dry matter accumulation in soybean during the first four weeks after emergence, which may be important in soybean production since that period is considered to be critical for weed competition with soybeans. After 28 DAE plants recovered from herbicide injuries. Treated and control plants showed no difference in commercial yield at harvest time.

\section{REFERENCES}

BEYER, E.M.; DUFFY, M.J.; HAY, J.V.; SCHLUETER, D.D. Sulfonylureas. In: KEARNEY, P.C.; KAUFMAN, D.D. ed., Herbicides: chemistry, degradation and mode of action. New York: Marcel Dekker, 1988. p.117-189.

BROCK, J.L. Effects of the herbicides trifluralin and carbetamide on nodulation and growth of legume seedlings. Weed Res. , v.12, p.150 $154,1972$.
DUKE, S.O. Overview of herbicide .mechanisms of action. Environ. Health Perspect., v.87, p263-271, 1990.

EGLI, T.B.; GUFFY, R.D.; LEGGETT, J.E. Partitioning of assimilate between vegetative and reproductive growth in soybean. Agron. J., v.77, p.917-922, 1985

FEHR, W.R.; CAVINESS, C.E.; BURMOOD, D.T.; PENNINGTON, J.S. Stage of development descriptions for soybeans, Glycine $\max ($ L.) Merrill. Crop Sci., v.11, p.929-931, 1971.

KUST, C.A.; STRUCKMEYER, B.E. Effects of tr if lu ralin on growth, no dulation, and an at omy of soybeans. Weed Sci., v.19, p.147-152, 1971.

MARENCO, R.A.; LOPES, N.F. Leaf chlorophyll concen tration and ni trog en content in soybean plants treated with herbicides. Rev.

Bras. Fisiol. Veg., v.6, p.7-13, 1994.

MARENCO, R.A.; LOPES, N.F.; MOSQUIM, P.R. Nodulation and nitrogen fixation in soybeans treated with herbicides. Rev. Bras. Fisiol. Veg., v.5, p.121-126, 1993.

PEOPLES, M.B.; GIFFORD, R.M. Long-distance transport of nitrogen and carbon from sources to sinks in higher plants. In: DENNIS, D.T. ; TURPIN, D.H., ed., Plant physiology, biochemistry and molecular biology. London: Longman Scientific Technical. 1990. p.434-447.

RADFORD, P.J. Growth analysis formulae - their use and abuse. Crop Sci., v.7, p.171-175, 1967. 